\title{
Epidemiology of Malocclusion and Assessment of Orthodontic Treatment Need for Nepalese Children
}

\author{
Varun Pratap Singh ${ }^{1}$ and Amita Sharma \\ ${ }^{1}$ Department of Orthodontics, Nobel Medical College \& Teaching Hospital, Biratnagar 56700, Nepal \\ ${ }^{2}$ Department of Dentistry, SHKM Government Medical College, Mewat, Haryana 122107, India \\ Correspondence should be addressed to Varun Pratap Singh; varundc@gmail.com
}

Received 25 August 2014; Accepted 8 December 2014; Published 22 December 2014

Academic Editor: Apolinaras Zaborskis

Copyright (C) 2014 V. P. Singh and A. Sharma. This is an open access article distributed under the Creative Commons Attribution License, which permits unrestricted use, distribution, and reproduction in any medium, provided the original work is properly cited.

\begin{abstract}
Objective. To evaluate the prevalence of malocclusion and orthodontic treatment needs among 12- to 15-year-old schoolchildren in eastern Nepal and compare the findings with those of other populations. Methods. Two thousand seventy-four children (1149 males and 925 females) aged between 12 and 15 years were evaluated. Their orthodontic treatment need was assessed using the Index of Orthodontic Treatment Needs (IOTN) (dental health component (DHC)). Angle's classes of malocclusion were also evaluated. Results. The prevalence of classes I, II, and III was $48.50 \%, 32.68 \%$, and $4.32 \%$, respectively. The IOTN showed that $21.59 \%$ had an extreme treatment need, $24.67 \%$ had severe treatment need, $24.07 \%$ had moderate treatment need, $14.7 \%$ had mild treatment need, and $15.02 \%$ had no treatment need. Conclusion. Class I malocclusion is the most common, while class III is the least prevalent in eastern Nepal. The majority of the children need orthodontic treatment.
\end{abstract}

\section{Introduction}

Epidemiology of malocclusion and assessment of orthodontic treatment needs are of national importance in many countries and were thus included in numerous national level surveys [1-16]. Malocclusion features the third highest prevalence among oral pathologies, secondarily to dental caries and periodontal disease and therefore ranks third among worldwide public health dental disease priorities. According to World Health Organization the main oral diseases should be subjected to periodic epidemiologic surveys. These assessments are necessary to plan sufficient treatment facilities and develop adequate training programs for respective specialists [17].

Malocclusions can be assessed with various methods [1823] but not one has gained universal acceptance. The Index of Orthodontic Treatment Need (IOTN) was developed to grade malocclusion on the basis of the significance of various occlusal traits for dental health and esthetic impairment [23]. The IOTN incorporates a dental health component (DHC) based on the recommendations of the Swedish medical board and an esthetic component [24]. Several prevalence studies have been conducted on children in mixed or permanent dentitions [25-33]. However, prevalence of malocclusion and orthodontic treatment needs for Nepalese children had not yet been reported in the indexed literature. Therefore, the present study aims to assess the epidemiology of malocclusion and orthodontic treatment needs in Nepalese schoolchildren aged 12-15 years in Eastern Nepal using IOTN index and compare these data with that of other population.

\section{Materials and Methods}

This study was conducted after ethical clearance from institutional review board, BP Koirala Institute of Health Sciences and permission from concerned school authorities. Consent was obtained from all parents before recording data. The sample comprised two thousand seventy-four children (1149 males and 925 females) from twenty high schools consisting of both public and private schools.

The subjects from the selected schools were included only if their chronological age was 12-15 years and if they were permanent inhabitants of Nepal. Those who were 
TABLE 1: Age and gender distribution of the study participants.

\begin{tabular}{lcccc}
\hline Sex & $n$ & $\%$ & Mean age & SD \\
\hline Males & 1121 & 55.77 & 13.9 & 5.7 \\
Females & 889 & 44.22 & 12.5 & 5.7 \\
\hline Total & 2010 & 100 & 13.5 & 5.8 \\
\hline
\end{tabular}

Age (in years) and gender distribution. ( $n=$ number of patients and $\mathrm{SD}=$ standard deviation).

undergoing orthodontic treatment or who had completed orthodontic treatment earlier or suffering from any other systemic diseases were excluded from the study.

The examiner and recording assistant were trained prior to the commencement of the study to ensure reliability. A validation exercise was conducted during the study and subsamples of $10 \%$ were reexamined to check intraexaminer variability, which was found to be satisfactory (Kappa value $=$ 0.8). The examination for malocclusion was made according to the molar relationship (Angle) and the criteria laid down by DHC of IOTN. In addition the presence of anterior spacing, a feature overlooked by the $\mathrm{DHC}$ was evaluated. The orthodontic treatment need was assessed. All the data was analyzed with SPSS software (Version 16.0 for Windows @ 2007 SPSS INC., NY, USA) and descriptive statistics were calculated.

\section{Results}

Out of 2074 children selected for the study, 14 did not return the signed parental consent document, 45 were not present at school on the assessment day, and 5 had already started orthodontic treatment.

The age distribution of the remaining 2010 children, according to the gender, is presented in Table 1.

Most children exhibited some type of malocclusion. Angle's class I malocclusion was found in $48.50 \%$ of all children, class II div. 1 in $29.35 \%$, class II div. 2 in 3.33\%, class III in $4.32 \%$, and normal occlusion in $14.42 \%$ (Table 2).

Table 3 shows the percentage scores of individual malocclusion traits according to the DHC of the IOTN.

Crowding was the most common type of malocclusion presented by the study group (19.75\%) followed by increased overjet (17.51\%) and deep overbite (13.23\%). Features like scissor bite $(0.89 \%)$, reverse overjet $(1.79 \%)$, and open bite $(2.03 \%)$ were least noticed in the study group.

The IOTN (DHC) showed the following distribution: Grade $1-15.02 \%(n=302)$; Grade $2-14.7 \%(n=296)$; Grade $3-24.07 \%(n=484)$; Grade $4-24.67 \%(n=496)$; Grade $5-21.59 \%(n=432)$. Grades 3 and 4 were more commonly observed in Nepalese children followed by Grades 5 and 1 (Table 4).

\section{Discussion}

The present study was designed to provide information about the prevalence of malocclusion and orthodontic treatment needs among 12- to 15-year-old school going children. Although assessment of malocclusion in nongrowing
TABLE 2: Distribution of malocclusion according to Angle's classification.

\begin{tabular}{lcccc}
\hline Malocclusion & Males & Females & Total & Percentage \\
\hline $\begin{array}{l}\text { Angle's class I } \\
\text { Angle's class II }\end{array}$ & 557 & 418 & 975 & 48.50 \\
$\begin{array}{l}\text { div. I } \\
\begin{array}{l}\text { Angle's class II } \\
\text { div. II }\end{array}\end{array}$ & 340 & 250 & 590 & 29.35 \\
$\begin{array}{l}\text { Angle's class III } \\
\begin{array}{l}\text { Normal } \\
\text { occlusion }\end{array}\end{array}$ & 31 & 30 & 68 & 3.33 \\
\hline Total & 155 & 135 & 87 & 4.32 \\
\hline
\end{tabular}

TABLE 3: Prevalence (\%) and distribution of individual malocclusion traits as per DHC of IOTN.

\begin{tabular}{lcccc}
\hline $\begin{array}{l}\text { Individual } \\
\text { malocclusion traits }\end{array}$ & Males & Females & Total & $\%$ \\
\hline Increased overjet & 192 & 160 & 352 & 17.51 \\
Reverse overjet & 21 & 15 & 36 & 1.79 \\
Crossbite & 53 & 39 & 92 & 4.57 \\
Deep overbite & 141 & 125 & 266 & 13.23 \\
Open bite & 21 & 20 & 41 & 2.03 \\
Scissor bite & 11 & 7 & 18 & 0.89 \\
Crowding mild & 30 & 23 & 53 & 19.75 \\
$\quad$ Moderate & 69 & 61 & 130 & \\
$\quad$ Severe & 132 & 82 & 214 & \\
Hypodontia & 54 & 26 & 80 & 3.90 \\
Impacted teeth & 72 & 44 & 116 & 5.77 \\
Submerged & & & & \\
deciduous & 41 & 31 & 72 & 3.50 \\
teeth & & & & \\
Supernumerary & 28 & 34 & 62 & 3.08 \\
teeth & & & & \\
Anterior spacing & 89 & 87 & 176 & 8.75 \\
Normal occlusion & 167 & 135 & 302 & 15.02 \\
\hline Total & 1121 & 889 & 2010 & 100 \\
\hline
\end{tabular}

population is more reliable, this range was chosen because it represents the majority of schoolchildren with developing malocclusion who require orthodontic treatment. The distribution of malocclusion and treatment needs among schoolchildren in Nepal had not yet been reported in the literature. In our study $14.42 \%$ had a normal occlusion, $48.50 \%$ had class I, 29.35 had class II div. I, 3.33\% had class II div. II, and $4.32 \%$ had class III. The frequency of Angle's class I malocclusion in this study was similar to that reported by Proffit et al. [1] in United States but less than Chinese [16] and Turkish [32] populations. The frequency of Angle's class II malocclusion was, however, higher than that being reported in United States [1], Turkish [32], and Chinese populations [16]. In case of class III malocclusion, the frequency was higher than that in United States [1] population but less than that of Chinese [16] and Turkish populations [32]. The difference in the frequency of the various Angle's classes in all 
TABLE 4: Relationship between the IOTN (DHC) grades and study population.

\begin{tabular}{lcccc}
\hline IOTN (DHC) & Males & Females & Total & Percentage \\
\hline $\begin{array}{l}\text { Grade 1-no need for } \\
\text { treatment }\end{array}$ & 161 & 141 & 302 & 15.02 \\
$\begin{array}{l}\text { Grade 2-mild/little } \\
\text { need }\end{array}$ & 159 & 137 & 296 & 14.7 \\
$\begin{array}{l}\text { Grade } \\
\begin{array}{l}3-\text { moderate/borderline } \\
\text { need }\end{array}\end{array}$ & 292 & 192 & 484 & 24.07 \\
$\begin{array}{l}\text { Grade 4-severe } \\
\text { treatment need }\end{array}$ & 251 & 245 & 496 & 24.67 \\
$\begin{array}{l}\text { Grade 5-extreme } \\
\text { treatment need }\end{array}$ & 258 & 174 & 432 & 21.59 \\
\hline \begin{tabular}{l} 
Total \\
\hline
\end{tabular} & 1121 & 889 & 2010 & 100 \\
\hline
\end{tabular}

these studies can mainly be explained by differences in sample size and ethnicity.

In this study crowding was the most common individual malocclusion trait as in accordance with studies in Maltese [38] and Brazilian [17] populations. The high prevalence of crowding can partially be explained by the great incidence of carious lesions and extractions of deciduous molars which favours migration of the first permanent molars as well as inclinations and rotations. However, scissor bite was the least common malocclusion in this study as in Maltese [38] population while in Brazilian population [17] ankylosed deciduous teeth were the least common trait.

Table 5 compares the finding of dental health component of IOTN in various studies in different populations.

The present investigation showed a greater frequency of Grades 4 and 5 which is severe and extreme treatment needs. This is due to a greater frequency of impacted, submerged deciduous teeth and hypodontia; further differences in sample size, study design, and ethnicities of the sample may account for differences in result.

One can note that the same type of malocclusion falls into different levels of orthodontic treatment need according to its severity. Therefore, the degree and priority of orthodontic treatment need among populations, which are important factors in public health planning, cannot be fully known by just evaluating the malocclusion prevalence [39]. If no specific index is used, determination of who really needs treatment becomes difficult and arbitrary, particularly among dentists and pediatric dentists, who end up inappropriately referring their patients to orthodontic treatment. In the present study, however, the normative evaluation based on the Index of Orthodontic Treatment Need may not be enough because of the often inherent elective nature of this treatment. As a result, other factors such as perceptual, functional, and social needs may interfere with treatment demand and service planning since those factors does not always coincide with the professional evaluation of treatment need. Therefore, further studies investigating the patient's perception and his or her concern regarding orthodontic treatment should be carried out in order to enhance the IOTN efficacy [40, 41].
TABLE 5: The data for various IOTN studies as compared to the present study in terms of IOTN (DHC) grades.

\begin{tabular}{|c|c|c|c|c|c|}
\hline Study & Grade 1 & Grade 2 & Grade 3 & Grade 4 & Grade 5 \\
\hline $\begin{array}{l}\text { Brook and Shaw } \\
\text { (United Kingdom), } \\
1989[34]\end{array}$ & $7.2 \%$ & $27.92 \%$ & $32.13 \%$ & $27.62 \%$ & $5.10 \%$ \\
\hline $\begin{array}{l}\text { So and Tang } \\
\text { (Turkey), } 1993 \text { [35] }\end{array}$ & $2 \%$ & $21 \%$ & $25 \%$ & $49 \%$ & $3 \%$ \\
\hline $\begin{array}{l}\text { Burden and } \\
\text { Holmes (United } \\
\text { Kingdom), } 1994 \\
{[36]}\end{array}$ & $5.03 \%$ & $40.96 \%$ & $24.02 \%$ & $20.02 \%$ & $9.45 \%$ \\
\hline $\begin{array}{l}\text { Hamdan (Jordan), } \\
2001 \text { [37] }\end{array}$ & $9.3 \%$ & $40.93 \%$ & $22.18 \%$ & $20.31 \%$ & $7.18 \%$ \\
\hline $\begin{array}{l}\text { Camilleri and } \\
\text { Mulligan (Malta), } \\
2007 \text { [38] }\end{array}$ & $13.96 \%$ & $15.09 \%$ & $28.86 \%$ & $25.84 \%$ & $16.22 \%$ \\
\hline $\begin{array}{l}\text { Current study } \\
\text { (Nepal), } 2013\end{array}$ & $15.02 \%$ & $14.7 \%$ & $24.07 \%$ & $24.67 \%$ & $21.59 \%$ \\
\hline
\end{tabular}

\section{Conclusion}

Angle's class I malocclusion is the most common while Angle's class III is the least prevalent malocclusion in eastern Nepalese schoolchildren. The pattern of malocclusion in this population sample is in general similar to that published in the international literature. It differs in the fact that this population have a high number of Grade 1 but a lower number of Grade 2 treatment needs of DHC of IOTN. Further this population exhibits a higher number of Grade 5 treatment needs emphasizing an extreme treatment need.

\section{Conflict of Interests}

The authors declare that there is no conflict of interests regarding the publication of this paper.

\section{References}

[1] W. R. Proffit, H. W. Fields Jr., and L. J. Moray, "Prevalence of malocclusion and orthodontic treatment need in the United States: estimates from the NHANES III survey," The International Journal of Adult Orthodontics and Orthognathic Surgery, vol. 13, no. 2, pp. 97-106, 1998.

[2] R. Burgersdijk, G. J. Truin, F. Frankenmolen, H. Kalsbeek, M. van't Hof, and J. Mulder, "Malocclusion and orthodontic treatment need of 15-74-year-old Dutch adults," Community Dentistry and Oral Epidemiology, vol. 19, no. 2, pp. 64-67, 1991.

[3] T. D. Foster and A. J. W. Day, "A survey of malocclusion and the need for orthodontic treatment in a Shropshire school population," British Journal of Orthodontics, vol. 1, no. 3, pp. 7378, 1974.

[4] S. al-Emran, P. J. Wisth, and O. E. Böe, "Prevalence of malocclusion and need for orthodontic treatment in Saudi Arabia," Community Dentistry and Oral Epidemiology, vol. 18, no. 5, pp. 253-255, 1990.

[5] B. R. de Muñiz, "Epidemiology of malocclusion in Argentine children," Community Dentistry and Oral Epidemiology, vol. 14, no. 4, pp. 221-224, 1986. 
[6] S. Helm, S. Kreiborg, J. Barlebo et al., "Estimates of orthodontic treatment need in Danish schoolchildren," Community Dentistry and Oral Epidemiology, vol. 3, no. 3, pp. 136-142, 1975.

[7] T. Ansai, H. Miyazaki, Y. Katoh et al., "Prevalence of malocclusion in high school students in Japan according to the Dental Aesthetic Index," Community Dentistry and Oral Epidemiology, vol. 21, no. 5, pp. 303-305, 1993.

[8] E. Ghabrial, W. A. Wiltshire, S. T. Zietsman, and E. Viljoen, "The epidemiology of malocclusion in Zambian urban school children," Journal of the South African Dental Association, vol. 53, no. 8, pp. 405-408, 1998.

[9] S. Haynes, "Orthodontic treatment needs in English children aged 11-12 years," British Journal of Orthodontics, vol. 1, no. 1, pp. 9-12, 1974.

[10] P. A. Hill, "The prevalence and severity of malocclusion and the need for orthodontic treatment in 9-, 12-, and 15-year-old Glasgow schoolchildren," British Journal of Orthodontics, vol. 19, no. 2, pp. 87-96, 1992.

[11] B. Ingervall, B. Mohlin, and B. Thilander, "Prevalence and awareness of malocclusion in Swedish men," Community Dentistry and Oral Epidemiology, vol. 6, no. 6, pp. 308-314, 1978.

[12] J. K. Luffingham and H. M. Campbell, "The need for orthodontic treatment. A pilot survey of 14 year old school children in Paisley, Scotland," Transactions. European Orthodontic Society, pp. 259-267, 1974.

[13] B. Prahl-Andersen, “The need for orthodontic treatment," Angle Orthodontist, vol. 48, no. 1, pp. 1-9, 1978.

[14] L. Salonen, B. Mohlin, B. Goötzlinger, and L. Helldén, "Need and demand for orthodontic treatment in an adult Swedish population," European Journal of Orthodontics, vol. 14, no. 5, pp. 359-368, 1992.

[15] B. Thilander and N. Myrberg, "The prevalence of malocclusion in Swedish school children," Scandinavian Journal of Dental Research, vol. 81, no. 1, pp. 12-21, 1973.

[16] K. K. Lew, W. C. Foong, and E. Loh, "Malocclusion prevalence in an ethnic Chinese population," Australian Dental Journal, vol. 38, no. 6, pp. 442-449, 1993.

[17] D. I. Brito, P. F. Dias, and R. Gleiser, "Prevalence of malocclusion in children aged 9 to 12 years old in the city of nova friburgo, rio de Janeiro State, Brazil," Revista Dental Press de Ortodontia e Ortopedia Facial, vol. 14, no. 6, pp. 118-124, 2009.

[18] H. L. Draker, "Handicapping labio-lingual deviations: a proposed index for public health purposes," American Journal of Orthodontics, vol. 46, no. 4, pp. 295-305, 1960.

[19] R. M. Grainger, Orthodontic Treatment Priorty Index, Public Health Service Publication no. 1000, Series 2, no. 25, Government Printing Office, Washington, DC, USA, 1967.

[20] J. A. Salzmann, "Handicapping malocclusion assessment to establish treatment priority," American Journal of Orthodontics, vol. 54 , no. 10, pp. 749-765, 1968.

[21] C. J. Summers, "The occlusal index: a system for identifying and scoring occlusal disorders," The American Journal of Orthodontics, vol. 59, no. 6, pp. 552-567, 1971.

[22] S. Linder-Aronson, "Orthodontics in the Swedish public dental health service," Transactions of the European Orthodontic Society, pp. 233-240, 1974.

[23] P. H. Brook and W. C. Shaw, "The development of an index of orthodontic treatment priority," European Journal of Orthodontics, vol. 11, no. 3, pp. 309-320, 1989.

[24] R. Evans and W. Shaw, "Preliminary evaluation of an illustrated scale for rating dental attractiveness," European Journal of Orthodontics, vol. 9, no. 1, pp. 314-318, 1987.
[25] F. Behbehani, J. Årtun, B. Al-Jame, and H. Kerosuo, "Prevalence and severity of malocclusion in adolescent Kuwaitis," Medical Principles and Practice, vol. 14, no. 6, pp. 390-395, 2005.

[26] Y. Ben-Bassat, D. Harari, and I. Brin, "Occlusal traits in a group of school children in an isolated society in Jerusalem," British Journal of Orthodontics, vol. 24, no. 3, pp. 229-235, 1997.

[27] R. J. Drummond, Orthodontic status and treatment need of 12year-old children in South Africa: an epidemiological study using the dental aesthetic index [Dissertação Mestrado em Odontologia], School of Dentistry, University of Pretoria, Pretoria, South Africa, 2003.

[28] N. H. El-Mangoury and Y. A. Mostafa, "Epidemiologic panorama of dental occlusion," The Angle Orthodontist, vol. 60, no. 3, pp. 207-214, 1990.

[29] H. Kerosuo, T. Laine, V. Nyyssonen, and E. Honkala, "Occlusal characteristics in groups of Tanzanian and Finnish urban schoolchildren," Angle Orthodontist, vol. 61, no. 1, pp. 49-56, 1991.

[30] C. A. Sadakyio, V. V. Degan, G. P. Neto, and R. M. P. Rontani, "Prevalência de má oclusão em pré-escolares de PiracicabaSP," Ciência Odontológica Brasileira, vol. 7, no. 2, pp. 92-99, 2004.

[31] F. K. Saleh, "Prevalence of malocclusion in a sample of Lebanese schoolchildren: an epidemiological study," Eastern Mediterranean Health Journal, vol. 5, no. 2, pp. 337-343, 1999.

[32] M. Ö. Sayin and H. Türkkahraman, "Malocclusion and crowding in an orthodontically referred turkish population," Angle Orthodontist, vol. 74, no. 5, pp. 635-639, 2004.

[33] A. A. Suliano, P. C. Borba, and M. J. Rodrigues, "Prevalência de más oclusões e alterações funcionais entre escolares assistidos pelo Programa Saúde da Família em Juazeiro do Norte, Ceará, Brasil," Revista Dental Press de Ortodontia e Ortopedia Facial, vol. 10, no. 6, pp. 103-110, 2005.

[34] P. H. Brook and W. C. Shaw, "The development of an index of ort hodontic priorty," The European Journal of Orthodontics, vol. 11, pp. 309-320, 1989.

[35] L. L. So and E. L. Tang, "A comparative study using the Occlusal Index and the Index of Orthodontic treatment need," Angle Orthodontist, vol. 63, no. 1, pp. 57-64, 1993.

[36] D. J. Burden and A. Holmes, "The need for orthodontic treatment in the child population of the united kingdom," European Journal of Orthodontics, vol. 16, no. 5, pp. 395-399, 1994.

[37] A. M. Hamdan, "Orthodontic treatment need in Jordanian school children," Community Dental Health, vol. 18, no. 3, pp. 177-180, 2001.

[38] S. Camilleri and K. Mulligan, "The prevalence of malocclusion in Maltese schoolchildren as measured by the index of orthodontic treatment need," Malta Medical Journal, vol. 19, no. 1, pp. 19-24, 2007.

[39] E. A. Mugonzibwa, A. M. Kuijpers-Jagtman, M. A. Van't Hof, and E. N. Kikwilu, "Need for orthodontic treatment among Tanzanian children," East African Medical Journal, vol. 81, no. 1, pp. 10-15, 2004.

[40] M. T. Chew and A. K.-L. Aw, "Appropriateness of orthodontic referrals: self-perceived and normative treatment needs of patients referred for orthodontic consultation," Community Dentistry and Oral Epidemiology, vol. 30, no. 6, pp. 449-454, 2002.

[41] M. J. Bentele, K. W. L. Vig, S. Shanker, and F. M. Beck, "Efficacy of training dental students in the index of orthodontic treatment need," American Journal of Orthodontics and Dentofacial Orthopedics, vol. 122, no. 5, pp. 456-462, 2002. 


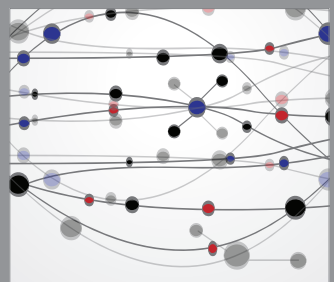

The Scientific World Journal
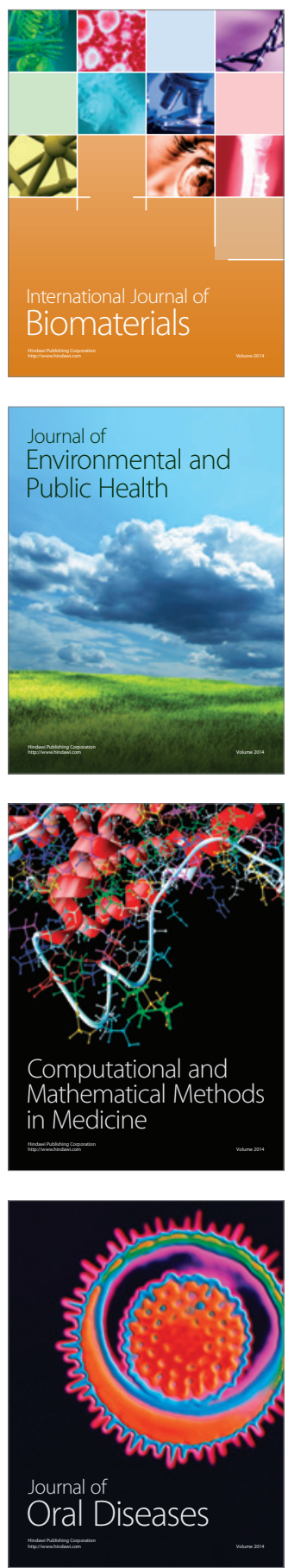
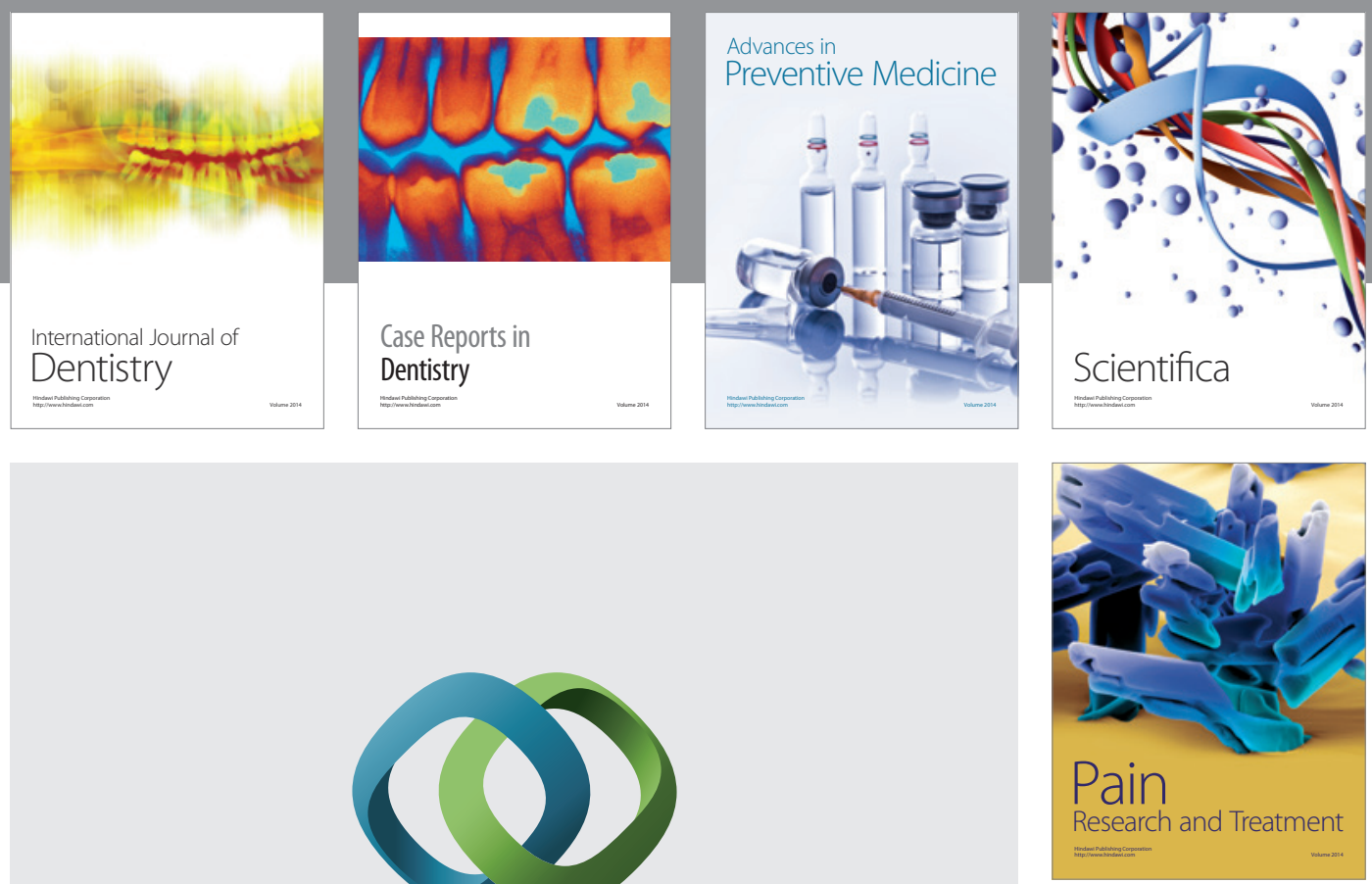

\section{Hindawi}

Submit your manuscripts at

http://www.hindawi.com
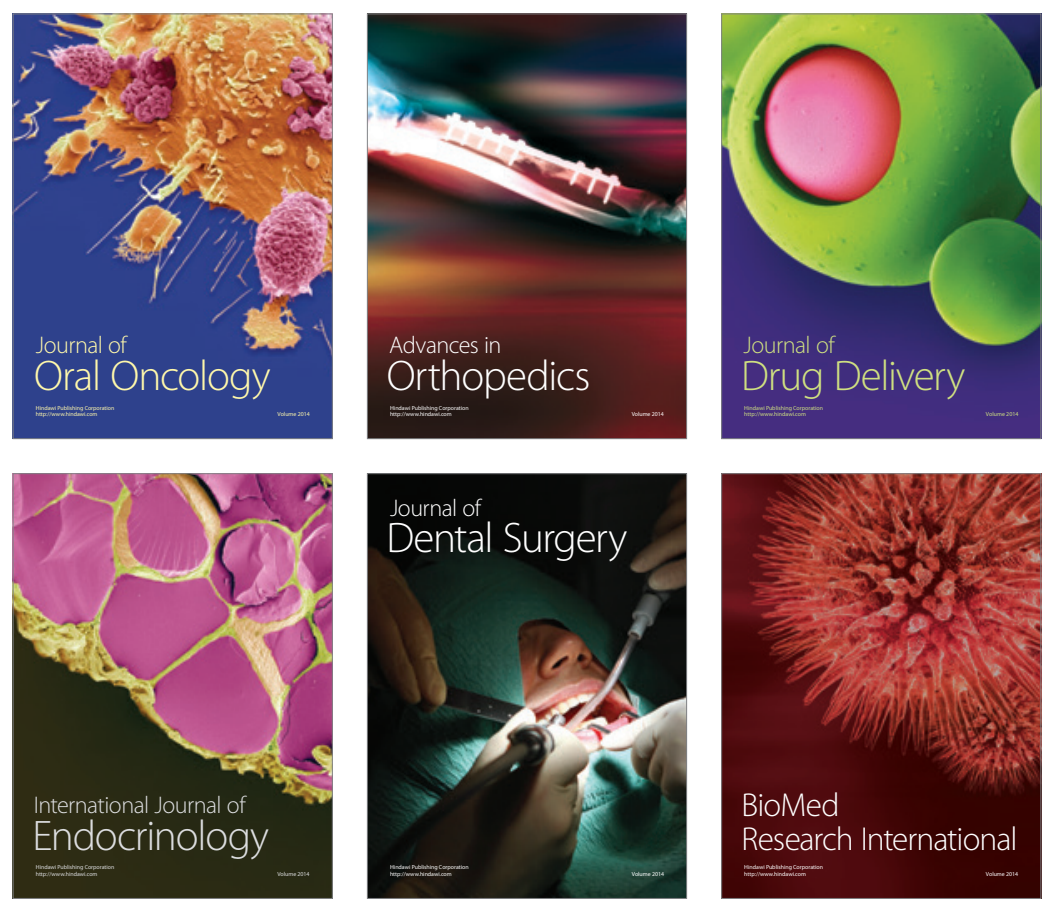

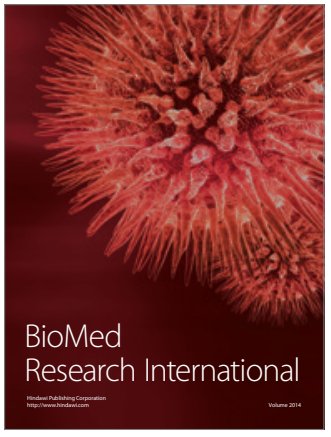

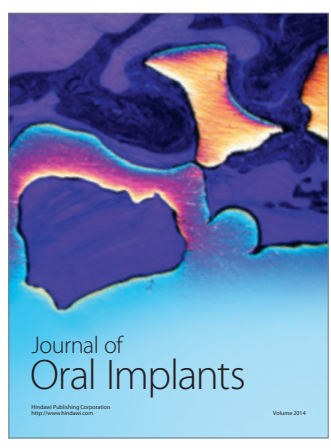
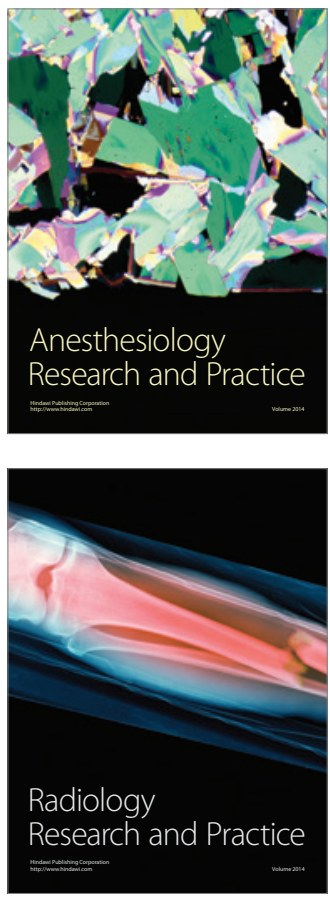